\title{
REVOLUSI HIJAU KEBIJAKAN EKONOMI PEMERINTAH BIDANG PERTANIAN DI KANAGARIAN SELAYO TAHUN 1974-1998
}

\section{GREEN REVOLUTION ECONOMIC POLICY AGRICULTURE IN KANAGARIAN SELAYO 1974-1998}

\author{
${ }^{1}$ Desma Yulia \\ ${ }^{1}$ (Program Studi Pendidikan Sejarah, Fakultas Keguruan dan Ilmu Pendidikan, Universitas Riau Kepulauan \\ Indonesia) \\ IDesmayulia48@gmail.com
}

\begin{abstract}
Abstrak
Revolusi hijau sebagai sebuah kebijakan yang menyangkut kesejahteraan masyarakat membawa dampak yang signifikan terhadap perkembangan kehidupan masyarakat Selayo. Tujuan penelitian ini adalah untuk mendeskripsikan pelaksanaan dan dampak Revolusi Hijau terhadap kebijakan ekonomi pemerintah bidang pertanian di Kanagarian Selayo tahun 1974-1998. Penelitian ini termasuk kualitatif deskriptif dengan metode penelitian sejarah. Langkah awal dalam penelitian ini adalah heuristik, kritik, interpretasi dan historiografi. Hasil penelitian ini adalah kanagarian selayo, merupakan daerah yang mempunyai peranana yang cukup signifikan terhadap Kabupaten Solok sebagai pensuplai beras, juga sebagai daerah yang cukup berperan dan mendukung Kabupaten Solok dalam mendapatkan julukan sebagai lumbung pangan untuk propinsi Sumatera Barat. Pada awal pelaksanaan revolusi hijau di Kanagarian Selayo melalui bimas dan inmas produksi padi menunjukkan hasil yang luar biasa, terbukti pada tahun 1983 mencapai 8,5 ton/ha dari 3,8 ton/ha pada tahun 1970. Setelah adanya kebijakan Revolusi Hijau, para petani dihadapkan pada siklus ketergantungan dan kemiskinan dan terjerat pada hutang. Asupan pertanian seperti pupuk, benih, pestisida yang sebelum revolusi hijau dikuasai oleh petani sendiri, sekarang petani terpaksa membelinya secara terus menerus. Sebagai akibat dari pemakaian bahan kimia yang terus menerus sawah menjadi semakin kurang subur, sehingga untuk memperbaikinya pada setiap musim tanam memerlukan input asupan luar semakin banyak.
\end{abstract}

\section{Kata Kunci: Revolusi Hijau, Ekonomi, Pertanian}

\begin{abstract}
Green revolution as a policy concerning public welfare has a significant impact on the development of the lives of the Selayo people. The purpose of this study was to describe the implementation and impact of the Green Revolution on government economic policies in agriculture in Kanagarian Selayo in 1974-1998. This research includes descriptive qualitative with historical research methods. The initial steps in this study are heuristic, criticism, interpretation and historiography. The results of this study are kanagarian selayo, which is a region that has a significant role in Solok Regency as a supplier of rice, as well as an area that has sufficient role and supports Solok Regency in obtaining a nickname as a food granary for the province of West Sumatra. Pada awal pelaksanaan revolusi hijau di Kanagarian Selayo melalui bimas dan inmas produksi padi menunjukkan hasil yang luar biasa, terbukti pada tahun 1983 mencapai 8,5 ton/ha dari 3,8 ton/ha pada tahun 1970. After the Green Revolution policy, farmers were faced with a cycle of dependence and poverty and became entangled in debt. Agricultural intake such as fertilizers, seeds, pesticides which before the green revolution were controlled by farmers themselves, now farmers are forced to buy it continuously. As a result of the continuous use of chemicals the fields become increasingly infertile, so that to improve them during each planting season requires more input from the outside.
\end{abstract}

Keywords: Green Revolution, Economic, Agriculture 


\section{PENDAHULUAN}

Revolusi hijau di Indonesia dicanangkan pemerintah Orde Baru pada awal tahun 1968/1969an. Pencanangan Revolusi Hijau ini bertujuan sebagai sarana yang akan meningkatkan produksi pangan, khususnya produksi beras secara luar biasa, dengan asumsi bahwa dengan kelimpahan produksi maka akan meningkatkan kesejahteraan rakyat petani. Melalui Program-program bimbingan massal (bimas), intensifikasi massal (inmas) kemudian dikembangkan kegiatan melalui kelompok tani seperti intensifikasi khusus (insus) yang juga sebagai perangkat untuk membantu petani meningkatkan produktivitas usaha taninya telah diadakan misalnya, dalam hal kelembagaan, penyuluhan, kredit, pemasaran dan koperasi dengan harapan dapat merubah tingkat kehidupan petani (Arifin, 2001: 90).

Selama pelaksaan program revolusi hijau dari tahun ke tahun telah terjadi peningkatan produksi padi. Terbukti pada decade 1970-an, Indonesia yang pada saat itu masih mengimpor 1,5 juta ton beras per tahun, tetapi pada tahun 1985 Indonesia mampu mengekspor 1,5 juta ton beras. Antara tahun 1968 sampai tahun 1984, produksi beras meningkat rata-rata sekitar 5\% per tahun. Namun, kesuksesan ini tidak bertahan lama (Hall, 1997:196).

Pengaruh yang dirasakan akibat dari Revolusi Hijau bagi petani pemilik sawah dan pemiliki modal pada waktu itu merupakan suatu kekaguman karena pendapatan dan penghasilan mereka meningkat, namun bagi penggarap dan pengolah sawah lainnya merupakan suatu kekecewaan karena tenaga mereka tidak dibutuhkan lagi. Pengaruh lain dari Revolusi Hijau yakni terpinggirkannya pertanian ekologis yang didasarkan kepada prinsip-prinsip keberlanjutan, yakni keanekaragaman varietas, kekhasan ekologis lokal dan keseimbangan ekosistem, bertani seimbang dengan hama dan predator. Siklus air, siklus hara, kesuburan tanah, seimbang dengan siklus pembenihan, penanaman, pemanenan, dan bertani yang bukan hanya sekedar memelihara pembaharuan ekosistem. Tetapi lebih dari itu mempertahankan pembaharuan kehidupan yakni kemandirian masyarakat petani. Setiap musim tanam sebagian benih yang dipanen pada musim sebelumnya ditanamkan kembali oleh petani (Arifin, 2001: 112). 
Nagari Selayo merupakan daerah dimana sebagian besar masyarakatnya hidup dari bertani khususnya padi. Kegiatan pertanian yang dilakukan oleh masyarakat tani di Selayo dalam mengolah lahan pertanian untuk ditanami padi sawah sebelum adanya revolusi hijau masih memanfaatkan peralatan tradisional. Hal ini terbukti dari cara membajak sawah yaitu dengan menggunakan tenaga hewan seperti sapi dan kerbau, sampai kepada pemupukan dan penggunaan bibit masih menggunakan bibit-bibit tradisional ( wawancara dengan Ir. Lasrizal). Artinya sebelum revolusi hijau masuk masuk ke Indonesia pada tahun 1968, Kanagarian Selayo sudah merupakan daerah yang mempunyai peranan yang cukup signifikan terhadap Kabupaten Solok sebagai penghasil beras jika dibandingkan dengan daerah yang lain, terbukti pada tahun 1968 produksi padi Selayo mencapai 3,2 ton/ha, sementara daerah lainnya hanya mencapai 2-2,7 ton/ha. Kanagarian Selayo juga merupakan salah satu daerah yang cukup berperan dan mendukung Kabupaten Solok dalam mendapatkan julukan sebagai lumbung pangan untuk Propinsi Sumatera Barat.

Tahun 1974-1975 setelah terjadinya krisis pengadaan beras di Kanagarian Selayo akibat kegagalan panen, yang berdampak pada melonjaknya harga beras, maka dalam rangka mengatasi hal tersebut pemerintah melalui tokoh-tokoh masyarakat pada suatu acara adat yang disebut bakaua memperkenalkan program revolusi hijau, kepada kalangan masyarakat petani Nagari Selayo. Bakaua merupakan suatu acara adat dalam bentuk ucapan terimakasih kepada Allah ats rezki yang diberikannya. Acara ini diselenggarakan setela para petani menerima hasil panen, dilaksanakan di daerah Sawah Kandang Jorong Batu Palano yang merupakan daetah terdapatnya "kapalo banda". Acara ini dihadiri oleh para pemuka masyarakat seperti, ninik mamak, alim ulama, cadiak pandai, bundo kanduang, penghulu, pemerintah serta dinas pertanian (UPTD Pertanian dan Perikanan, 2002: 42)

Berdasarkan hasil pengamatan yang penulis dapat dari beberapa petani di Kanagarian Selayo, setelah adanya kebijakan Revolusi Hijaumaka para petani Selayo dihadapkan pada siklus ketergantungan dan kemiskinan, terjerat pada hutang dan terpinggirkan oleh mekanisme pasar. Asupan pertanian seperti pupuk, benih, pestisida yang sebelum revolusi hijau dikuasai oleh petani sendiri sekarang petani terpaksa membelinya secara terus menerus. Sebagai akibat pemakaian bahan kimia yang secara terus menerus sawah menjadi kurang subur, sehingga untuk 
memperbikinya pada setiap musim tanam memerlukan input asupan luar semakin banyak. Sedangkan nilai tukar dari apa yang diproduksi terhadap teknologi yang diproduksi yang dipakai terus mengalami penurunan. Berdasarkan asalan-alasan di atas penulis tertarik untuk memperoleh gambaran dan pemahaman konkrit tentang pelaksanaan dan pengaruh Revolusi Hijau bagi kebijakan ekonomi di Kanagarian Selayo sejak tahun 1974-1998 secara mendalam melalui penelitian sejarah.

\section{Kerangka Konseptual}

Pendekatan yang digunakan dalam penelitian ini yaitu konsep modernisasi, dalam arti khusus yang disepakati teoritis modernisasi di tahun 1950-an dan tahun 1960-an yang didefinisikan dalam tiga cara yaitu: historis, relative dan analisis. Menurut definisi historis, modernisasi sama dengan westernisasi, modernisasi dilihat sebagai gerakan menuju ciri-ciri masyarakat yang dijadikan model. Berikut ini dikutip dua contoh pandangan seperti itu, eisenstadt mengatakan: secara historis modernisasi adalah proses perubahan menuju tipe sosial, ekonomi dan politik yang maju di Eropa Barat dan Amerika serta Negara Eropa lainnya.

Wilber Moore (dalam Piotr Sztompka, 1993: 152) menyatakan modernisasi sebagai proses dari masyarakat tradisional atau pra teknologi yang ditransformasikan ke masyarakat yang menggunakan teknologi mesin. Pernyataan ini diperkuat oleh Lewis bahwa modernisasi adalah sebagai pertumbuhan output dari setiap individu kelompok masyarakat untuk kelangsungan pembangunan ekonomi. Pembangunan ekonomi itu berlangsung melalui modernisasi teknologi yang membawa perubahan dari teknik-teknik tradisional kepada aplikasi ilmu pengetahuan pertanian komersial yang bercirikan pergeseran dari pertanian subsistensi menuju pertanian ekspor dan spesialisasi terhadap produksi yang akan diperdagangkan. Proses industrialisasi yang menggambarkan transisi dari penggunaan kekuatan hewan dan manusia menuju penggunaaan tenaga mesin.

Menurut Masher (1976:132), teknologi pertanian adalah cara-cara dalam pertanian dalam usaha meningkatkan produktifitas seperti traktor lebih produktif dari pada cangkul. Pupuk buatan lebih produktif dari pada pupuk kandang, dan pemakaian bibit unggul supaya cepat panen dan menghasilkan kualitas yang baik. Peranan teknologi baru dalam pembangunan pertanian 
mengakibatkan perubahan dalam produksi maupun distribusi, seperti yang terjadi di Kanagarian Selayo Kecamatan Kubung dengan adanya program Revolusi Hijau.

Revolusi hijau bagi masyarakat Selayo merupakan kekaguman sekaligus kekecewaan. Bagi petani pemilik sawah dan pemilik modal revolusi hijau merupakan suatu kekaguman karena pendapatan dan penghasilan mereka meningkat namun bagi penggarap dan pengolah sawah laiinya revolusi hijau merupakan suatu kekecewaan karena tenaga mereka tidak dibutuhkan lagi. Pengaruh dari revolusi hijau ini sangat dirasakan oleh para perempuan yang tertutup sumber penghasilan utamanya tanpa ada lapangan kerja baru sebagai pengganti.

\section{METODOLOGI}

Langkah-langkah dalam penelitian revolusi hijau kebijakan ekonomi pemerintah di bidang pertanian di Kanagarian Selayo tahun 1974-1998 ini tidak terlepas dari metode dasar sejarah, yang dilakukan melalui beberapa tahapan, heuristik, kritik, interpretasi, dan penulisan.

1. Tahapan pertama heuristik yaitu mengumpulkan dan menghimpun data yang relevan dengan topik penelitian data yang di ambil dalam penelitian ini berasal dari sumber primer dan sumber sekunder. Selanjutnya

2. Tahap kedua yaitu kritik sumber, baik internal maupun internal, adalah melakukan pengujian terhadap keaslian dan kesahihan informasi. kritik eksternal yaitu dengan cara melakukan pengujian otensitas dokumen. Kritik internal adalah yang dilakukan untuk menguji kesahihan informasi yang diperoleh melalui arsip atau dokumen.

3. Tahapan yang ketiga adalah interpretasi yaitu dengan cara menghimpun data yang terkumpul kemudian memilah-milah dengan menyeleksi data yang dianggap relevan dengan kajian penelitian yaitu data tentang pelaksanaan kebijakan ekonomi revolusi hijau yang dilakukan pemerintah untuk mengubah kehidupan masyarakat desa Kanagarian Selayo.

4. Tahap yang terakhir yaitu penulisan sejarah dimana data yang telah diuji kebenarannya itu dirangkai dan dihubungkan dengan konsep dan teori yang dikemukan. Setelah didapatkan fakta sejarah yang akurat maka dilakukan penulisan sejarah. 


\section{PEMBAHASAN}

\section{A. Pelaksanaan Revolusi Hijau di Kanagarian Selayo}

Kebijakan ekonomi pertanian dalam bentuk usaha intensikasi pertanian padi sawah telah diperkenalkan di Nagari Selayo pada tahun 1970-an. Setahun kemudian usaha intensifikasi dalam bentuk program bimas dilaksanakan di Selayo. Pada awal pelaksanaannya, program bimas menghadapi berbagai kendala, seperti kurangnya tenaga pegawai penyuluh lapangan (PPL). Persoalan lain yang dihadapi adalah keengganana para petani untuk merubah pola tanam yang telah mereka lakukan sejak dahulu. Para petani di Selayo tidak berani untuk merubah cara-cara bertanam dengan alasan belum melihat hasil dari cara-cara baru tersebut. Namun kemudian dinas pertanian Kabupaten Solok memanfaatkan acara adat bakaua untuk meyakinkan masyarakat Selayo tentang program Revolusi Hijau, karena masyarakat Selayo sangat kental dengan adat istiadatnya, melalui ini masyarakat Selayo mulai menerapkan program-program dari Revolusi hijau.

Penerapan teknologi baru dalam pertanian pada akhirnya akan mengakibatkan perubahan dalam masyarakat. Perubahan-perubahan yang terjadi antara lain adalah frekuensi tanaman yang meningkat dari sekali setahun menjadi dua atau tiga kali setahun. Pada gilirannya hal ini akan berakibat meningkatnya pengetahuan masyarakat tentang cara bertani yang dapat meningkatkan hasil pertanian, serta merembesnya ekonomi komersil dalam kehidupan pedesaan (Kirkpatrick, 1996: 86).

Dilihat dari proses penyebaran teknologi baru di tengah masyarakat Nagari Selayo, maka pembangunan irigasi dan penerapan panca usaha tani melalui program Bimas merupakan factor pokok yang mempengaruhi masyarakat Selao. Penerapan panca usaha tani dalam pertanian padi sawah di Selayo membawa berbagai perubahan dalam pertanian padi seperti pengadaan bibit, tenaga kerja, pupuk, dan perubahan-perubahan dalam system panen padi. Selanjutnya juga akan mengakibatkan perubahan dalam distribusi pendapatan para petani di Selayo.

Dalam pelaksanaan pembangunan pertanian, khususnya subsector pertanian tanaman padi bukan saja diperlukan pembangunan sarana fisik, seperti ekstensifikasi atau intensifikasi lahan dan pembangunan irigasi, tetapi juga penyediaan sarana dan prasarana yang mendukung 
pelaksanaan pertanian padi tersebut, berupa pupuk, obat-obtan dan sebagainya. Proses peningkatan produksi padi akan sangat tergantung pada kesempurnaan panca usaha tani, yang terdiri dari bibit unggul, pengairan, teknik bercocok tanam, pupuk serta pemberantasan hama dan penyakit.

Jika dikaitkan dengan peralatan yang ada pada tahun 1984 di Kanagarian Selayo hanya ada tiga unit traktor tangan, yang penggunaan terbatas pada sawah yang dekat dengan jalan dan tanahnya tidak berbatu (wawancara dengan Rustam Dt. Saga Batuah). Hal ini disebabkan karena pada waktu itu mekanisme alat pertanian, seperti traktor tangan belum dikenal secara laus, akibatnya pengolahan tanah yang dilakukan tidak sempurna, untuk menanggulangi hal tersebut petani menggunakan system "julo-julo" dalam menggarap sawah.

\section{B. Dampak Revolusi Hijau Sebagai Kebijakan Ekonomi Pertanian di Kanagarian Selayo \\ 1. Dampak Positif Revolusi Hijau bagi Petani di Kanagarian Selayo.}

Pada tahun sebelum 1970-an atau sebelum diperkenalkannya program bimas dan inmas di Selayo, para petani masih menggunakan bibit padi lokal, seperti "padi tamun sasak, padi putiah, dan padi randang kolam”. Jenis bibit lokal ini umumnya berumur panjang, yaitu 6-7 bulan, akibatnya pada saat itu penanaman padi sawah hanya dilakukan satu kali. Setelah adanya kebijakan revolusi hijau yang menerapkan kepada masyarakat berupa teknologi baru dalam bertani dengan cara menggunakan alat-alat modern, produksi beras Selayo mengalami peningkatan dari tahun ke tahun, produksi beras pada tahun 1969 yaitu 3,2 ton pertahun, pada tahun 1970 meningkat menjadi 3,8, pada tahun 1983 produksi padi yang dihasilkan petani mencapai 8,5 ton per hektar ton dan terus meningkat.

Terjadinya peningkatan produksi padi tersebut, para petani di Selayo mulai meninggalkan kebiasaan lama dalam bertani padi sawah. Penggunaan bibit lokal mulai ditinggalkan, terutama disebabkan oleh varietas lokal tidak tahan terhadap hama pianggang yang sering melanda sawah petani Selayo pada saat itu. Bibit unggul dapat diperoleh melalui kredit pertanian. 


\section{Dampak Negatif Revolusi Hijau bagi Petani di Kanagarian Selayo}

Pada dasarnya keberadaan revolusi hijau di satu sisi telah membawa perubahan besar terutama bagi kehidupan petani baik petani pemilik sawah maupun petani penggarap. Sejalan dengan hal itu, perkembangan ekonomi yang dari tahun ke tahun tidak tetap, mengakibatkan tidak sebandingnya nilai tukar hasil pertanian dengan harga input-input pertanian yang terus mengalami kenaikan. Hal ini membuktikan bahwa pelaksanaan revolusi hijau membuat petani terperangkap ke dalam teknologi yang tidak mampu dia ciptakan. Petani dijadikan sebagai pemakai atau "tukang" asupan luar. Sedangkan nilai tukar dari apa yang diproduksi terhadap teknologi yang dipakai terus mengalami penurunan.

Dilihat dari proses penyebaran teknologi baru di masyarakat Nagari Selayo, maka pembangunan irigasi dan penerapan panca usaha tani melalui program bimas merupakan faktor pokok yang mempengaruhi masyarakat Selayo. Penerapan panca usaha tani dalam pertanian padi sawah di Selayo membawa berbagai perubahan dalam pertanian padi seperti pengadaan bibit, tenaga kerja, pupuk dan perubahan-perubahan dalam system panen padi. Selanjutnya juga akan mengakibatkan perubahan dalam distribusi pendapatan para petani di Selayo.

Secara umum dapat dikatakan penerapan panca usaha tani dalam bentuk program bimas di Selayo tahun 1990-an belumlah berjalan sebagaimana mestinya. Pemakaian bibit unggul yang ideal adalah maksimal empat kali musim tanam, setelah itu harus diganti dengan bibit unggul mencapai enam sampai delapan musim tanam. Hal ini mempengaruhi produksi sawah petani penggarap, sehingga tidak mencukupi untuk kebutuhan rumah tangga mereka. Alasan yang dikemukakan petani penggarap adalah mereka tidak mampu membeli bibit unggul baru, atau kalau petani penggarap memakai bibit unggul baru, berarti mereka akan menambah hutang.

Pada saat program Insus dan Supra Insus dilaksanakan di Nagari Selayo, para petani tetap mengikuti dengan pertimbangan sesuai dengan kemampuannya. Sedangkan sarana produksi pertanian yang diperoleh tetap dengan cara mengutang ke kios-kios terdekat yang memberikan kepercayaan kepadanya. Para petani mengakui penggunaaan teknologi 
baru dalam pertanian padi sawah telah mampu meningktakan hasil sawahnya, tetapi biaya untuk memperoleh sarana produksi tersebut juga relative besar, sedangkan untuk menggunakan kredit pemerintah, mereka tidak mau berurusan dengan administrasi Koperasi Unit Desa (KUD) yang cukup berbelit-belit.

Kesulitan-kesulitan yang dihadapi para petani disamping kerusakan lahan juga sangat merugikan petani pekerja sawah atau penggarap karena program revolusi hijau ini tenaga manusia sebagai penggarap tidak begitu diperlukan lagi, karena sebagian pekerjaan yang biasanya dikerjakan oleh petani sudah digantikan dengan mesin, sehingga pendapatan petani penggarap berkurang, biasanya setiap panen padi para pemilik tanah sudah mencari penggarap untuk membantu panen padinya, semenjak mengenal revolusi hijau pemilik sawah tidak begitu memerlukan penggarap lagi. Namun bagi pemilik sawah program revolusi hijau sangat menguntungkan bagi mereka, karena hasil panen mereka meningkat dan lebih berkualitas.

\section{KESIMPULAN DAN SARAN}

\section{Kesimpulan}

Kanagarian Selayo memiliki peranan cukup signifikan terhadap Kabupaten Solok sebagai penghasil beras bila dibandingkan dengan daerah lain seperti Nagari Guguak, Nagari Talang, Nagari Cupak dan Nagari Koto Ilalang terbukti pada tahun 1968 produksi padi di Selayo mencapai 3,2 ton/ha, sementara daerah lainnya hanya mencapai 2-2,7 ton/ha. Kanagarian Selayo juga merupakan salah satu daerah yang cukup berperan dan mendukung Kabupaten Solok dalam mendapatkan julukan sebagai lumbung pangan untuk Propinsi Sumatera Barat terutama dari produksi padi, terbukti pada tahun 1968 produkai padi di Selayo bisa mencapai 3,2 ton gabah untuk setiap hektarnya. Kebijakan revolusi hijau di Nagari Selayo bersamaan dengan dimulainya Pelita I tepatnya pada tahun 1974-1975 yaitu setelah terjadinya krisis pengadaan beras akibat kegagalan panen yang mengakibatkan melonjaknya harga beras. Dalam rangka mengatasi hal tersebut pemerintah melalui tokoh-tokoh masyarakat pada suatu acara adat yang disebut Bakaua memperkenalkan program Revolusi Hijau kepada kalangan masyarakat oetani Nagari Selayo. 
Pelaksanaan revolusi hijau di Nagari Selayo dilihat dari sisi produksi padi membawa perubahan yang cukup signifikan terbukti dengan meningkatnya produksi padi yang dihasilkan dari tahun ke tahun.

Pada tahun 1975 program Bimas dari Revolusi hijau menunjukkan keberhasilannya disebabkan oleh semakin intensifnya penyuluhan pertanian dan subsidi yang yang telah diberikan pemerintah kepada para petani di Selayo. Subsidi yang telah diberikan tersebut meningkatkan produksi padi di Selayo yang mencapai puncaknya pada tahun 1997 dengan hasil 8,9 ton/ha. Revolusi hijau sebagai sebuah kebijakan yang menyangkut kesejahteraan masyarakat, memberikan dampak yang signifikan terhadap perkembangan kehidupan masyarakat Selayo, dampak positif akibat dari pelaksanaan revolusi hijau antara lain dari segi produksi meningkatnya hasil panen, namun dari segi kehidupan sosial ekonomi bagi penggarap sangat menyengsarakan.

\section{Saran}

Sebagai bagin dari sejarah pertanian revolusi hijau tidak pernah kering untuk terus digali adalah suatu kesalahan fatal bahwa revolusi hijau adalah permasalahn usang yang tidak perlu ditulis kembali. Melihat berbagai bentuk penulisan hasil karya sejarah tentang revolusi hijau dan berdasarkan perkembangan baru arah penulisan sejarah pertanian, maka penulis menyarankan adanya penulsi lain yang menuliskan sejarah revolusi hijau yang dialami oleh masyarakat Indonesia yang berada di daerah lainnya. Tentunya penulisan ini dapat memperkaya khasanah penulisan sejarah lokal tentang pertanian di Indonesia yang sangat mempengaruhi kehidupan masyarakat Indonesia.

\section{REFERENSI}

\section{Majalah}

Hira Jhamtani. “Salah Urus Perekonomian Indonesia” dalam Salam No 12 tahun 2005. Panthius, John. “Awal Perkembangan Revolusi Hijau dengan Pertanian Organis". Dalam Prisma Edisi 2 tahun 1995.

P.Van der Elst. : Krisis Budidaya Padi di Jawa" dalam Prisma. No.2 tahun 1990. 
Scheltema, A.M.P.A."Produksi Beras di Jawa dan Madura" dalam Prisma, no. 2 tahun 1990.

\section{Buku}

Abbas, Syansuddin. 1997. Revolusi Hijau dan Swasembada Beras dan Jagung. Jakarta: Departemen Pertanian

Amler, S. John. 1990. Dinamika Irigasi Petani: Kerangka dan Prinsip-Prinsip Kelembagaan Pengelola Air Tradisional di Indonesia. Padang: PSI Unand.

Amran, Rusli. 1985. Sumatera Barat Plakat Panjang. Jakarta: Sinar Harapan.

Arifin, Bustanul. 2001. "Spektrum Kebijakan Pertanian Indonesia; Telaah, Strktur, Kasus, dan Alternatif Strategi. Jakarta: Erlangga.

Bahreint, Sugien. 1992. Sosiologi Pedesaan Suatu Pengantar. Jakarta: PT. Grafindo Persada.

BAPPEDA TK.II Kab.Solok.1989. Monografi Daerah Tingkat II Solok. Diklat. Solok:Bappeda TK II Solok.

Booth, Anne. 2001. Indonesia Beyond Soeharto. Negara, Ekonomi Masyarakat Transisi. Jakarta:PT. Gramedia Pustaka Utama.

Chamber, Robert. 1987. Pembanguna Desa Mulai dari Belakang. Terj. Jakarta: Departemen Pertanian RI.

Sepuluh Tahun Departemen Pertanian 1969-1979. Jakarta: Departemen Pertanian RI.

Fauzi, Noer. 1999. Petani dan Penguasa; Dinamika Perjalan Politik Agraria Indonesia. Yogyakarta: Fakultas Sastra UGM.

Gee. Kwik Kian. 1994. Analisis Ekonomi Politik Indonesia. Jakarta:PT Gramedia Pustaka Utama.

Geerts, Cliford. 1976. Involusi Pertanian Proses Perubahan Ekologi di Indonesia. Terj. S.Supomo. Jakarta: Bharata.

Gonggong, Anhar. 1990. Sejarah Industrialisasi. Jakarta: Departemen Pendidikan dan Kebudayaan Direktorat Sejarah dan Nilai Tradisional.

Gottschalk, Louis. 1998. Mengerti Sejarah. Jakarta:UI Press. 
Hill, Hal. 1997. Ekonomi Indonesia. Jakarta: Grafindo Persada

Kartosoepoetra. 1998. Teknologi Penyuluhan Pertanian. Jakarta: Bina Aksara

Kartodirjo, Sartono. 1984. Pemberontakan Petani Banten 1888. Terjemahan, Jakarta: Pustaka Jaya

Koencaraningrat. 1997. Metode-metode Penelitian Masyarakat. Jakarta: PT. Gramedia Pustaka Utama

Mubyarto. 1998. Pengantar Ekonomi Pertanian. Jakarta:LP3ES

UPTD Pertanian dan Perikanan. 2002. Pendapatan Perkapita Petani Selayo Kecamatan Kobung Kabupaten Solok.

Zed, Mestika. Dkk. 1992. Perubahan Sosial di Minangkabau Implikasi Kelembagaan Dalam Pembangunan Sumatera Barat. Padang: Pusat Studi Pembangunan dan Perubahan Sosial Unand. 